UDC $539.3 ; 514.182 .7$

\title{
COMPUTER MODELING AND OPTIMIZATION OF ENERGY EFFICIENCY POTENTIALS IN CIVIL ENGINEERING
}

\author{
O.P. Koshevyi, \\ candidate of technical science, associate professor \\ D.V. Levkivskyi, \\ candidate of technical science, associate professor \\ V.O. Kosheva, \\ candidate of technical science, assistant \\ A.S. Mozharovskyi, \\ post-graduate student

\begin{abstract}
Kyiv National University of Construction and Architecture, Povitroflotskyi Avenue, 31, Kyiv, 03680
\end{abstract}

DOI: $10.32347 / 2410-2547.2021 .106 .274-281$

The paper presents the results of creating a software package for optimizing the calculation of potentials of alternative energy sources in the regions of Ukraine based on BIM technologies (AutoCAD, ArchiCAD, Revit), which are combined using the IFC format. The software package uses mathematical and graph-analytical models of climate and energy zoning in the regions of Ukraine, and with the help of MS Excel visualizes the research process and automates, accelerates optimal decision in design, reconstruction and construction. The process of forming a database for traditional energy sources (electricity, oil products, natural gas, coal, firewood) and a database of energy potentials of alternative energy sources (solar energy, wind energy, geothermal energy, hydropower of small rivers, potentials of livestock and crop biomass potential of excess pressure of natural gas, potentials of heat of soil, ground and sewage, potentials of energy of peat and forest waste) for all regions of Ukraine. The structure of the software package and a block diagram has been developed, all indicators are reduced to a single unit of measurement $(\mathrm{MW} * \mathrm{~h} /$ year per 1000 people). To analyze and make optimal decisions, informative-illustrative bar and sector pie charts are built in MS Excel on five main areas of energy consumption, taking into account alternative energy sources for each region of Ukraine. The general analysis of energy consumption and optimization calculations are carried out with the help of informative-illustrative diagram SANKEY, which is created with the help of "SankeyDiagramGenerator", and visualizes the whole process of graph-analytical modeling of energy consumption in Ukraine.

Keywords: computer modeling, calculation optimization, traditional energy sources, potentials of alternative energy sources, energy efficient construction, BIM technologies, SANKEY modeling.

Introduction. The creation a software of optimization energy sources based on mathematical and graphical models of climatic and energy zoning of Ukraine for a comprehensive assessment of energy efficiency district and making optimal decisions, and their further implementation in the practice of design, construction and reconstruction of facilities in this area [1]. The developed software package for optimization and graphical presentation of energy efficiency results uses BIM tools (AutoCAD, ArchiCAD, Revit), which are combined using the IFC format, which allows to make optimal decisions

Koshevyi O.P., Levkivskyi D.V., Kosheva V.O., Mozharovskyi A.S. 
on energy efficiency of natural resources in the region of Ukraine. Using the capabilities of MS Excel complex visualizes the entire research process and accelerates and automates further opportunities for the development of integrated design, construction and reconstruction of buildings and structures [2].

1.Formation of a database. The development of the software package begins with the formation of a database of traditional energy sources of the regions of Ukraine in terms of five main areas of energy consumption: electricity (hydroelectric power, nuclear electricity, thermal electricity) in MW; petroleum products (motor gasoline, diesel fuel, fuel oil) in thousands of tons; natural gas in million $\mathrm{m} 3$; coal in thousands of tons; firewood thousand m3 (table 1).

Table 1

Traditional energy sources

\begin{tabular}{|l|l|l|l|l|l|l|}
\hline n/o & Region of & Electricity & $\begin{array}{l}\text { Petroleum } \\
\text { products }\end{array}$ & Coal & Natural gas & Firewood \\
\cline { 3 - 7 } & & $\begin{array}{l}\text { MW*h/year } \\
\text { per 1000 } \\
\text { people }\end{array}$ & $\begin{array}{l}\text { MW*h/year } \\
\text { per } \begin{array}{l}\text { MW*on/year } \\
\text { people }\end{array}\end{array}$ & $\begin{array}{l}\text { MW } \begin{array}{l}\text { MWh/year } \\
\text { people } \\
\text { per } 1000\end{array} \\
\text { people }\end{array}$ & $\begin{array}{l}\text { MW*h/year } \\
\text { per 1000 } \\
\text { people }\end{array}$ \\
\hline 1 & Vinnytsia & 1858,50 & 924,56 & 2674,65 & 2411,17 & 37,58 \\
\hline 2 & Volyn & 1545,40 & 912,87 & 149,01 & 2040,13 & 82,90 \\
\hline 3 & Dnepropetrovsk & 8669,95 & 1200,82 & 7550,02 & 6134,45 & 5,79 \\
\hline 4 & Donetsk & 4344,80 & 849,42 & 15464,84 & 5466,35 & 8,07 \\
\hline 5 & Zhytomyr & 2130,81 & 797,22 & 52,53 & 2488,38 & 216,99 \\
\hline 6 & Transcarpathian & 1511,77 & 929,90 & 46,75 & 1838,18 & 92,29 \\
\hline 7 & Zaporozhye & 5217,38 & 1071,64 & 5318,34 & 3192,30 & 9,99 \\
\hline 8 & Ivano-Frankivsk & 1602,04 & 840,98 & 4937,12 & 2715,72 & 23,50 \\
\hline 9 & Kyiv & 3115,23 & 1272,30 & 1098,77 & 4154,47 & 30,42 \\
\hline 10 & Kirovograd & 3384,28 & 1002,99 & 267,33 & 2303,65 & 37,10 \\
\hline 11 & Luhansk & 3624,82 & 1561,91 & 7755,46 & 5368,05 & 19,79 \\
\hline 12 & Lviv & 1724,12 & 892,80 & 880,90 & 2676,97 & 34,64 \\
\hline 13 & Nikolaev & 2652,29 & 1104,04 & 233,30 & 3676,45 & 17,82 \\
\hline 14 & Odessa & 2604,70 & 1171,54 & 104,67 & 3507,88 & 14,45 \\
\hline 15 & Poltava & 3784,53 & 1621,73 & 62,86 & 5184,61 & 21,85 \\
\hline 16 & Rivne & 2073,79 & 721,47 & 271,96 & 3450,61 & 90,60 \\
\hline 17 & Sumy & 2034,37 & 735,26 & 203,12 & 3357,04 & 129,88 \\
\hline 18 & Ternopil & 2199,11 & 780,84 & 49,85 & 2713,78 & 23,61 \\
\hline 19 & Kharkiv & 2616,24 & 754,18 & 2572,79 & 3959,51 & 41,93 \\
\hline 20 & Kherson & 2312,94 & 1089,09 & 123,97 & 1812,95 & 45,12 \\
\hline 21 & Khmelnytsky & 1027,91 & 880,05 & 699,13 & 2609,57 & 58,16 \\
\hline 22 & Cherkasy & 2652,63 & 1086,39 & 854,81 & 6210,26 & 64,81 \\
\hline 23 & Chernivtsi & 1437,46 & 772,22 & 82,69 & 1861,14 & 129,17 \\
\hline 24 & Chernihiv & 1889,15 & 757,03 & 1030,41 & 2986,14 & 154,64 \\
\hline 25 & Crimea & 594,59 & 864,44 & 151,55 & 2466,96 & 17,28 \\
\hline & & & & & & \\
\hline
\end{tabular}

Parallel, a database of energy potentials of alternative energy sources in the regions of Ukraine is being formed:

- solar energy potential $\left(\mathrm{MW}^{*} \mathrm{~h} /\right.$ year);

- expedient hydraulic potential of small rivers $\left(\mathrm{MW}^{*} \mathrm{~h} /\right.$ year$)$; 
- energy potential of livestock biomass (ton of fuel / year);

- energy potential of plant biomass (thousand $\mathrm{MW}^{*} \mathrm{~h} /$ year);

- energy potential of forest waste (tons of fuel / year);

- thermal potential of geothermal energy (MW);

- expedient economic potential of blast furnace gas overpressure energy resources (thousand $\mathrm{MW}^{*} \mathrm{~h} /$ year);

- expedient economic potential of excess natural gas pressure (thousand $\mathrm{MW} * \mathrm{~h} /$ year);

- expedient economic potential of peat (million $\mathrm{MW}^{*} \mathrm{~h} /$ year);

- expedient economic energy potential of soil and groundwater heat (thousand $\mathrm{MW}^{*} \mathrm{~h} /$ year);

- expedient economic potential of thermal energy of sewage (thousand $\mathrm{MW}^{*} \mathrm{~h} /$ year);

- technically achievable wind potential up to $60 \mathrm{~m}\left(\mathrm{~kW}^{*} \mathrm{~h} / \mathrm{m} 2\right)$, here the possibilities of using up to 200 thousand $\mathrm{m} 2$ of wind energy per region are taken into account (table 2) [3].

Table 2

Energy potentials of alternative energy sources in the regions of Ukraine

\begin{tabular}{|c|c|c|c|c|c|c|c|c|c|c|c|c|c|}
\hline $\mathrm{n} / \mathrm{o}$ & $\begin{array}{l}\text { Region of } \\
\text { Ukraine }\end{array}$ & 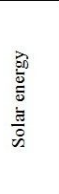 & 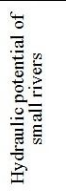 & 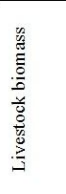 & 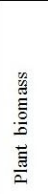 & 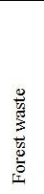 & 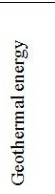 & 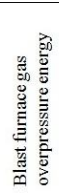 & 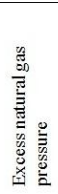 & 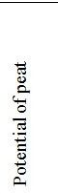 & 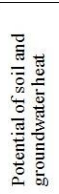 & 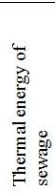 & $\frac{80}{\frac{0}{0}}$ \\
\hline 1 & Vinnytsia & 147,4 & 69,2 & 1301,8 & 43,7 & 12,9 & 0 & 0 & 25,0 & 22,2 & 328,8 & 153,2 & 48,1 \\
\hline 2 & Volyn & 154,5 & 33,9 & 1161,3 & 5,5 & 41,9 & 0 & 0 & 9,0 & 735,8 & 280,1 & 139,1 & 72,4 \\
\hline 3 & Dnepropetrovsk & 87,3 & 9,4 & 781,9 & 43,8 & 0 & 0 & 32,3 & 45,5 & 0 & 132,2 & 564,2 & 43,7 \\
\hline 4 & Donetsk & 60,01 & 13,7 & 434,3 & 24,0 & 0 & 0 & 25,3 & 32,4 & 0 & 637,6 & 368,0 & 41,3 \\
\hline 5 & Zhytomyr & 196,7 & 82,8 & 1354,2 & 8,9 & 30,1 & 0 & 0 & 12,3 & 130,5 & 350,8 & 153,3 & 61,5 \\
\hline 6 & Transcarpathian & 95,5 & 1079,7 & 439,8 & 8,1 & 0 & 115,6 & 0 & 4,4 & 0 & 62,9 & 113,0 & 162,3 \\
\hline 7 & Zaporozhye & 152,4 & 8,79 & 1030,5 & 59,4 & 0 & 0 & 14,8 & 46,9 & 0 & 208,1 & 337,7 & 100,9 \\
\hline 8 & IvanoFrankivsk & 87,4 & 87,4 & 595,4 & 5,1 & 5,0 & 0 & 0 & 39,3 & 13,0 & 37,1 & 249,0 & 148,6 \\
\hline 9 & Kyiv & 50,9 & 12,7 & 417,8 & 7,8 & 8,2 & 0 & 0 & 34,3 & 31,0 & 40,7 & 404,1 & 16,0 \\
\hline 10 & Kirovograd & 232,7 & 53,9 & 1419,2 & 97,1 & 0 & 0 & 0 & 7,7 & 0 & 881,0 & 178,7 & 148,1 \\
\hline 11 & Luhansk & 116,2 & 60,9 & 601,1 & 36,2 & 0 & 0 & 3,4 & 28,3 & 0 & 910,0 & 231,4 & 65,1 \\
\hline 12 & Lviv & 74,5 & 213,2 & 593,9 & 3,3 & 10,4 & 0 & 0 & 12,5 & 95,6 & 79,5 & 384,4 & 80,0 \\
\hline 13 & Nikolaev & 212,2 & 41,6 & 1042,8 & 55,5 & 0 & 478,6 & 0 & 20,3 & 0 & 103,4 & 216,6 & 123,8 \\
\hline 14 & Odessa & 142,9 & 4,6 & 702,6 & 42,2 & 0 & 191,5 & 0 & 11,8 & 0 & 82,0 & 273,5 & 72,3 \\
\hline 15 & Poltava & 171,4 & 84,9 & 1411,9 & 63,1 & 0 & 2,01 & 0 & 27,8 & 102,1 & 115,7 & 228,5 & 99,9 \\
\hline 16 & Rivne & 138,3 & 78,6 & 979,8 & 6,4 & 53,7 & 0 & 0 & 10,4 & 497,1 & 194,4 & 169,4 & 64,9 \\
\hline 17 & Sumy & 184,9 & 82,3 & 1348,9 & 29,8 & 15,9 & 4,5 & 0 & 28,7 & 530,1 & 221,0 & 158,1 & 69,4 \\
\hline 18 & Ternopil & 114,7 & 122,4 & 1223,4 & 19,3 & 12,3 & 0 & 0 & 10,5 & 109,8 & 185,5 & 134,8 & 71,8 \\
\hline 19 & Kharkiv & 100,9 & 29,9 & 771,9 & 34,6 & 0 & 0,15 & 0 & 39,6 & 0 & 57,2 & 395,8 & 52,3 \\
\hline 20 & Kherson & 279,5 & 0,9 & 1375,6 & 56,2 & 0 & 796,2 & 0 & 8,2 & 7,7 & 165,8 & 161,9 & 165,8 \\
\hline 21 & Khmelnytsky & 142,3 & 71,9 & 1423,7 & 34,0 & 12,6 & 0 & 0 & 10,3 & 78,3 & 135,2 & 160,5 & 59,3 \\
\hline 22 & Cherkasy & 149,2 & 82,0 & 1287,1 & 60,1 & 11,5 & 0 & 0 & 24,0 & 66,1 & 394,6 & 240,4 & 62,2 \\
\hline 23 & Chernivtsi & 77,4 & 293,0 & 765,5 & 22,3 & 6,6 & 0 & 0 & 5,6 & 0 & 136,0 & 109,5 & 225,6 \\
\hline 24 & Chernihiv & 258,5 & 53,7 & 1940,4 & 20,7 & 26,9 & 17,8 & 0 & 15,9 & 354,0 & 148,1 & 178,0 & 74,6 \\
\hline 25 & Crimea & 114,7 & 26,8 & 618,3 & 12,4 & 0 & 3025 & 0 & 12,3 & 0 & 87,5 & 202,6 & 86,6 \\
\hline
\end{tabular}

2. The structure of the software package. At the second stage of creation of the program complex the main indicators of energy consumption of the regions of Ukraine, as well as indicators of potentials of alternative energy sources are reduced to uniform units of $\mathrm{MW}^{*} \mathrm{~h} /$ year per 1000 people of the region and a hierarchy of its work is formed. The block diagram of the operation of the software package is presented in fig. 1. 
Informative and illustrative synthesizing bar charts for traditional energy sources are created, which show the energy consumption levels of the regions of Ukraine (electricity, oil, coal, natural gas, firewood) in $\mathrm{MW}^{*} \mathrm{~h} /$ year per 1000 people, which also reflect it as a percentage [4].

3. Optimization graphanalytical models of energy consumption. To make optimal decisions, the analysis of energy consumption is carried out taking into account the possible use of energy potentials of alternative energy sources of the regions of Ukraine in the form of informative and illustrative synthesizing pie charts in MS Excel. The diagrams highlight the sectors of possible replacement of traditional energy sources with alternatives in digital

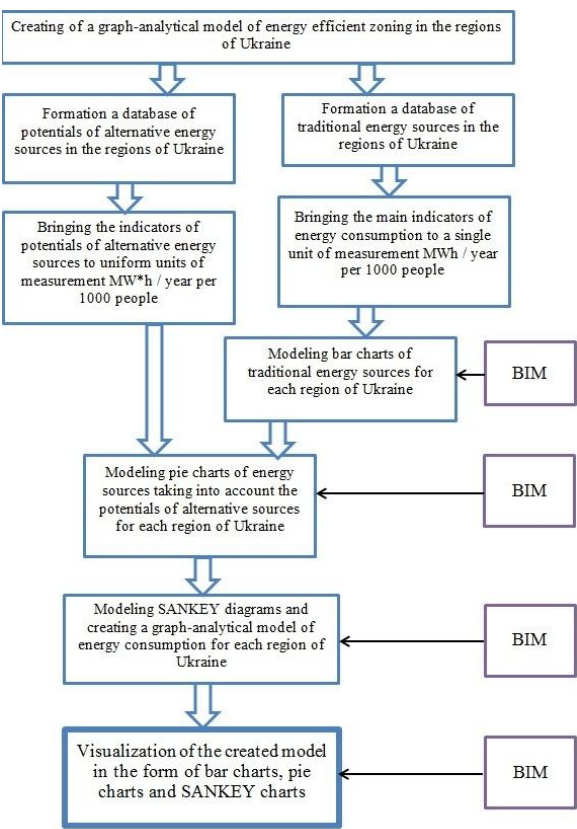

Fig. 1 and percentage values. In fig. 2 presents a bar chart of the existing energy consumption of the region of Ukraine and sectoral charts of optimization of energy sources in five areas on the example of Kyiv region.

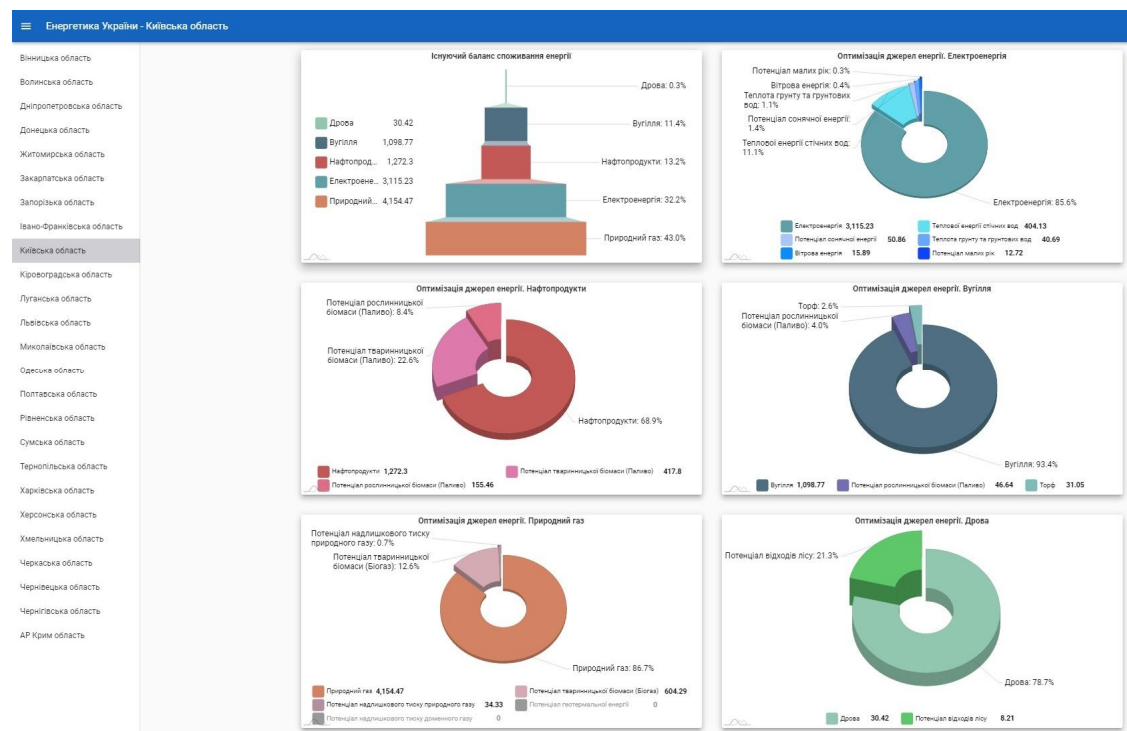

Fig. 2 
The general analysis of energy consumption is carried out with the help of informative-illustrative technological diagram SANKEY, which visualizes the whole process of graph-analytical modeling of energy consumption and optimizes the rational use of energy potentials of the regions of Ukraine. The decision-making process is divided into streams, the values of which are illustrated in digital and percentage ratios. The created SANKEY diagrams give the chance to move streams, to adjust their sizes, to cancel superfluous and to add new, and also to continue the analysis in other directions and with other parameters [5]. The SANKEY optimization diagram on the example of Kyiv region is showed in fig. 3 .

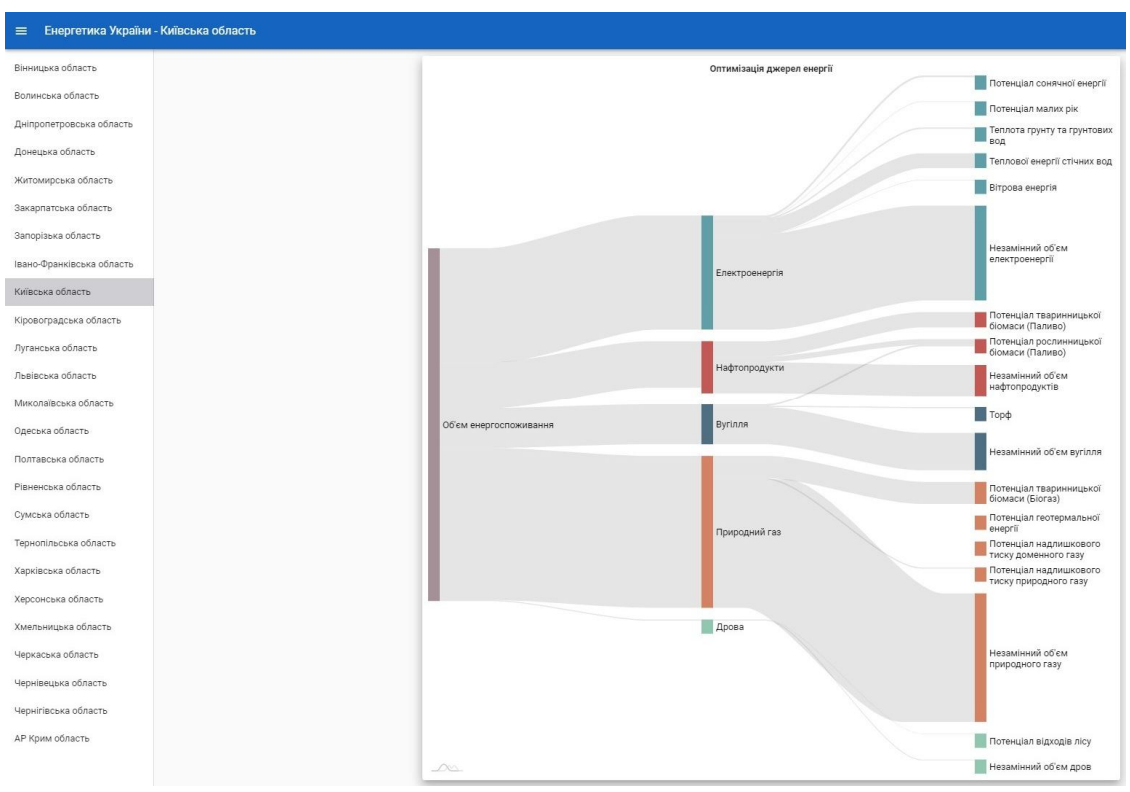

Fig. 3

4. Working with the software interface. The whole process of graphanalytical modeling of energy consumption in the regions of Ukraine is displayed on a computer screen. To the left of the column are the names of regions of Ukraine that are active, when you press "ENTER", when the cursor is on the name of the region, the whole process of modeling and the results of optimization of energy consumption in this area in separate "windows". The first window builds an initial bar chart of the region's existing energy consumption. Next, five pie charts are constructed showing the possibility of substituting electricity, oil products, coal, natural gas and firewood for the potentials of alternative energy sources that are achievable for this region of Ukraine. The process is summarized by modeling a SANKEY diagram that optimizes with graph-analytical modeling energy consumption and the choice of an efficient model for the selected region. 
Conclusions. The graph-analytical model of complex analysis and optimization of energy efficiency allows to assess the prospects of using the energy potentials of the regions of Ukraine, and to determine the most optimal directions of their introduction into the energy system to increase energy efficiency of buildings and structures. Modeling also allows us to visualize the decision-making process in the design of new and reconstruction of existing architectural objects, which greatly facilitates the work of designers, and lays the foundations for accurate selection of climatic parameters for further using. This model identifies the main directions in improving the energy efficiency of the regions, taking into account their potential of using of alternative energy sources, and provides an opportunity to form a comprehensive graph-analytical model of the building for further use and compilation of its energy passport.

The developed software package of optimization and graph-analytical modeling of energy efficiency of the regions of Ukraine automates the process of making optimal decisions in determining the energy consumption conditions of construction areas. General analysis of energy consumption and optimization calculations are performed using the informative-illustrative diagram SANKEY, which is created using "SankeyDiagramGenerator" and visualizes the whole process of graph-analytical modeling of energy consumption in Ukraine, which significantly accelerates decision-making in designing and identifying promising areas. The databases used for the operation of the software package can be updated with new data, which significantly expands the possibilities of using the software package in the future.

The results of research and a comprehensive optimization model of energy efficiency of areas in the regions of Ukraine are presented in the form of a software package posted on the site [6].

\section{REFERENCES}

1. Hetun $H$. V., Kosheva $V$. O. Aktualnist vykorystannya vidnovlyuvalnykh dzherel enerhiyi u budivelnomu sektori $v$ umovakh Ukrayiny (The peculiarities using of renewable energy sources in the contruction sector in Ukraine) // N.-t. zbirnyk «Enerhoefekyvnist $\mathrm{v}$ budivnytstvi ta arkhitekturi», vyp. 9, - K: KNUBA, 2017 r. - s. 44-48.

2. Kosheva $V$. O. Pobudova kompleksnoyi modeli funktsionuvannya enerhoaktyvnykh ob $\square$ yektiv arkhitektury (Creation of a complex model of functioning of energy-active objects of architecture) // N. t. zbirnyk «Prykladna heometriya ta inzhenerna hrafika». vyp. 98, - K.: KNUBA, 2020 r. - s. 74-84.

3. Kosheva V.O., Hetun H.V., Levkivskyy D.V. Pobudova kompleksnoyi modeli enerhoosnashchenosti rayoniv budivnytstva Ukrayiny (Creation of a complex model of energy equipment of construction areas of Ukraine) // N. t. zbirnyk «Mistobuduvannya ta terytorialne planuvannya», vyp. 73, - K.:KNUBA, 2020r., -320 s.156-167.

4. Infogram Generates Beautiful Infographics From Custom Data. DinamicInfogram. URL: https://ifehacker.com/infogr-am-generates-beautiful-infographics-from-custom-5992991 (Data zvernennya:20.02.2021).

5. Henerator diahram SANKEY (SANKEY chart generator). SankeyDiagramGenerator. URL: http://sankey-diagram-generator.acquireprocure.com/ (Data zvernennya :10.01.2021).

6. Doslidzhennya ta kompleksna model enerhoefektyvnosti rayoniv budivnytstva $\mathrm{v}$ rehionakh Ukrayiny (Research and complex model of energy efficiency of construction areas in the regions of Ukraine). URL: http://sopromat-knuba.com/energy/. 
Котевий О.П., Левківський Д.В., Кошева В.О., Можаровський А.С.

\section{КОМП'ЮТЕРНЕ МОДЕЛЮВАННЯ ТА ОПТИМІЗАЦІЯ ПОТЕНЦІАЛІВ ЕНЕРГОЕФЕКТИВНОСТІ В БУДІВНИЦТВІ}

В даній роботі наведені результати створення програмного комплексу оптимізаційного розрахунку потенціалів альтернативних джерел енергії в регіонах України на основі BIM технологій (AutoCAD, ArchiCAD, Revit), що об’єднуються за допомогою формату IFC. Програмний комплекс використовує створенні математичні та графоаналітичні моделі кліматичного та енергетичного районування в регіонах України, та за допомогою можливостей MS Excel візуалізує процес дослідження і автоматизує та прискорює прийняття оптимальних рішень при проектуванні, реконструкції та будівництві. Розглядається процес формування бази даних для традиційних джерел енергії (електроенергія, нафтопродукти, природний газ, вугілля, дрова), та бази даних енергетичних потенціалів альтернативних джерел енергії (сонячна енергія, вітрова енергія, геотермальна енергія, гідропотенціал малих рік, потенціали тваринницької та рослинницької біомаси, потенціал надлишкового тиску природного газу, потенціали теплоти грунту, грунтових та стічних вод, потенціали енергії торфу та відходів лісу) для всіх регіонів України. Розроблена структура функціонування програмного комплексу, де всі показники зводяться до єдиних одиниць виміру (МВт*год/рік на 1000 чол.) та блок-схема. Для аналізу i прийняття оптимальних проектних рішень будуються інформативноілюстративні стовпчикові та секторіальні кругові діаграми в середовищі MS Excel по п'яти основним напрямкам енергоспоживання з урахуванням альтернативних джерел енергії для кожного регіону України. Загальний аналіз енергоспоживання та оптимізаційні розрахунки проводяться за допомогою інформативно- ілюстративної діаграми SANKEY, яка створюється за допомогою «SankeyDiagramGenerator», та візуалізує весь процес графоаналітичного моделювання енергоспоживання регіонів України.

Ключові слова: комп'ютерне моделювання, оптимізація розрахунків, традиційні джерела енергії, потенціали альтернативних енергоджерел, енергоефективне будівництво, BIM технології, SANKEY моделювання.

\section{УДК $539.3 ; 514.182 .7$}

Кошевий О.П., Левківський Д.В., Кочева В.О., Можаровський А.С. Комп'ютерне моделювання та оптимізація потенціалів енергоефективності в будівництві // Опір матеріалів і теорія споруд: наук.-тех. збірник. - К.: КНУБА, 2021. - Вип. 106. - С. 274-281.

В статті наведені результати комп 'ютерного моделювання енергетичних потениіалів джерел енергї та створення комплексу програм оптимізачійних розрахунків для підвищення енергоефективності будівництва в регіонах Украӥни.

Табл. 2. Іл. 3. Бібліогр. 6 назв.

UDC $539.3 ; 514.182 .7$

Koshevyi O.P., Levkivskyi D.V., Kosheva V.O., Mozharovskyi A.S. Computer modeling and optimization of energy efficiency potentials in civil engineering // Strength of Materials and Theory of Structures: Scientific-and-technical collected articles - Kyiv: KNUBA, 2021. - Issue 106. - P. 274-281.

The paper shows the results of computer modeling potential of energy sources and the creation of software package for optimization calculations to increase energy efficiency of construction sector in the regions of Ukraine.

Tabl. 2. Il. 3. Ref. 6.

Автор (науковий ступінь, вчене звання, посада): кандидат технічних наук, доцент, завідуючий кафедри опору матеріалів КНУБА Комевий Олександр Петрович.

Адреса: 03680 Украӥна, м. Київ, Повітрофлотський проспект 31, КНУБА, кафедра опору матеріалів, Кошевий Олександр Петрович.

Робочий тел.: +38(044) 241-54-21;

Мобільний тел.: +38(050)-441-52-30;

E-mail: a0504415230@gmail.com

ORCID ID: https://orcid.org/0000-0002-7796-0443 
Автор (науковий ступінь, вчене звання, посада): кандидат технічних наук, доцент, доцент кафедри опору матеріалів КНУБА Левківський Дмитро Володимирович.

Адреса: 03680 Украӥна, м. Київ, Повітрофлотський проспект 31, КНУБА, кафедра опору матеріалів, Левківський Дмитро Володимирович.

Мобільний тел.: +38(096) 756-21-33;

E-mail: levkivskyi.dv@knuba.edu.ua

ORCID ID: https://orcid.org/0000-0003-2964-1605

Автор (науковий ступінь, вчене звання, посада): кандидат технічних наук, асистент кафедри архітектурних конструкиій КНУБА Кошева Вікторія Олександрівна.

Адреса: 03680 Украӥна, м. Київ, Повітрофлотський проспект 31, КНУБА, кафедра архітектурних конструкиій, Кошева Вікторія Олександрівна.

Мобільний тел.: +38(063) 277-96-76;

E-mail: vikk-ko@ukr.net

ORCID ID: https://orcid.org/0000-0002-6178-8837

Автор (науковий ступінь, вчене звання, посада): аспірант кафедри опору матеріалів КНУБА Можаровський Андрій Сергійович.

Адреса: 03680 Украӥна, м. Київ, Повітрофлотський проспект 31, КНУБА, кафедра опору матеріалів, Можаровський Андрій Сергійович.

Мобільний тел.: +38(063) 209-34-45;

E-mail: andrii.mozharovskyi@gmail.com

ORCID ID: https://orcid.org/0000-0003-2690-0296 